\title{
Communication
}

[Comunicação]

\section{Equine coital exanthema in a stallion}

\author{
[Herpesvirus equino 3 em um garanhão] \\ C. Ferreira ${ }^{1}$, E.A. Costa ${ }^{1}$, S.A. França ${ }^{1}$, U.P. de Melo ${ }^{1}$, B.P. Drumond ${ }^{2}$, M.R.Q. Bomfim ${ }^{3}$, \\ F.M. Coelho ${ }^{3}$, M. Resende ${ }^{3}$, M.S. Palhares ${ }^{1}$, R.L. Santos ${ }^{1 *}$ \\ ${ }^{1}$ Escola de Veterinária - UFMG \\ Av. Antonio Carlos, 6627 \\ 31270-901 - Belo Horizonte, MG \\ ${ }^{2}$ Centro de Pesquisas René Rachou - Fiocruz - Belo Horizonte, MG \\ ${ }^{3}$ Instituto de Ciências Biológicas - UFMG - Belo Horizonte, MG
}

Equine herpesvirus 3 (EHV-3), an alphaherpesvirus that causes self-limiting genital lesions in horses, is the etiologic agent of equine coital exanthema (ECE). ECE is an acute, usually mild, venereally transmitted disease characterized by papules, vesicles, pustules, and ulcers in the vaginal mucosa and vulva, penis, prepuce, and perineal region. Occasionally, lesions may involve the upper respiratory mucosa (Pascoe and Bagust, 1975; Pascoe, 1981). EHV-3 is usually transmitted by venereal route. However, there is evidence that non-sexual transmission may occur by fomites, fresh-chilled and frozen semen (Metcalf, 2001). The incubation period may be as short as two days. Although genital lesions may be extensive, there are no systemic clinical signs. In uncomplicated cases, healing is usually complete within 14 days. Healed lesions become depigmented (white) spots, which permanently mark affected areas and identify potential carriers (Bryans, 1980). Abortion and infertility are not associated with natural EHV-3 infection. Mares frequently conceive at the same time they acquire the disease (Murphy et al., 1999). Affected stallions have decreased libido and, therefore, the disease may disrupt breeding schedules. Recurrent disease is more likely to occur when stallions copulate more frequently. Management of the disease consists in symptomatic treatment and removal of affected stallions from service until all lesions are healed (Murphy et al., 1999). EHV-3 exhibits a latency-reactivation pattern similar to that of other alphaherpesviruses. Latency and subclinical infections may limit the

Recebido em 21 de setembro de 2009

Aceito em 10 de novembro de 2010

*Autor para correspondência (corresponding author)

E-mail: rsantos@vet.ufmg.br development of clinical signs in mares and/or stallions during the breeding season. These asymptomatic cases make difficult to monitor the disease (Seki et al., 2004; Barrandeguy et al., 2008). EHV-3 has been reported in many countries, including the United States (Crandell and Davis, 1985), Australia (Pascoe, 1981), Canada (Girard et al., 1968), Denmark (Bryans, 1980), Norway (Krogsrud and Onstad, 1971), England, and Japan (Seki et al., 2004).

In Brazil, stallions develop clinical lesions similar to those of ECE in the genital tract, but there are no published reports of confirmed etiologic diagnosis. Lesions are particularly common in embryo transfer centers. However, the presence of EHV-3 has not yet been documented in Brazil. Therefore, here it is described a case of clinical signs and histopathological findings compatible with ECE associated with detection of EHV-3 in a four-yearold Mangalarga Marchador stallion.

In August 2008, a four-year-old Mangalarga Marchador stallion developed swelling and purulent secretion in the prepuce, associated with a history of apathy and frequent recumbence. The horse came from a herd located in Sabará, central part of the State of Minas Gerais, Brazil. The herd was composed of four stallions and 25 mares. Due to the development of genital lesions, the stallion was not allowed to mate any mare, and the last copulation occurred four months before the development of lesions compatible with ECE. No other clinical changes were observed in any of the horses in the herd. 
Clinical examination revealed apathy, inappetence, and swelling of the prepuce and scrotum. There was small amount of purulent exudate draining from the prepuce, and numerous circular multifocal erosive lesions of approximately 0.2 to $1 \mathrm{~cm}$ diameter with an elevated hyperemic edge and ulcerated centers covered with a fibrinous yellowish exudate in the mucosa of the penis and prepuce (Figure 1). Some of these lesions were coalescing and there were a few vesicles. Ulcerations were also observed in the nasal mucosa, which were associated with bilateral mucopurulent nasal discharge. Clinical parameters including cerebral performance category, heart rate, rectal temperature, and pulse were within normal range.

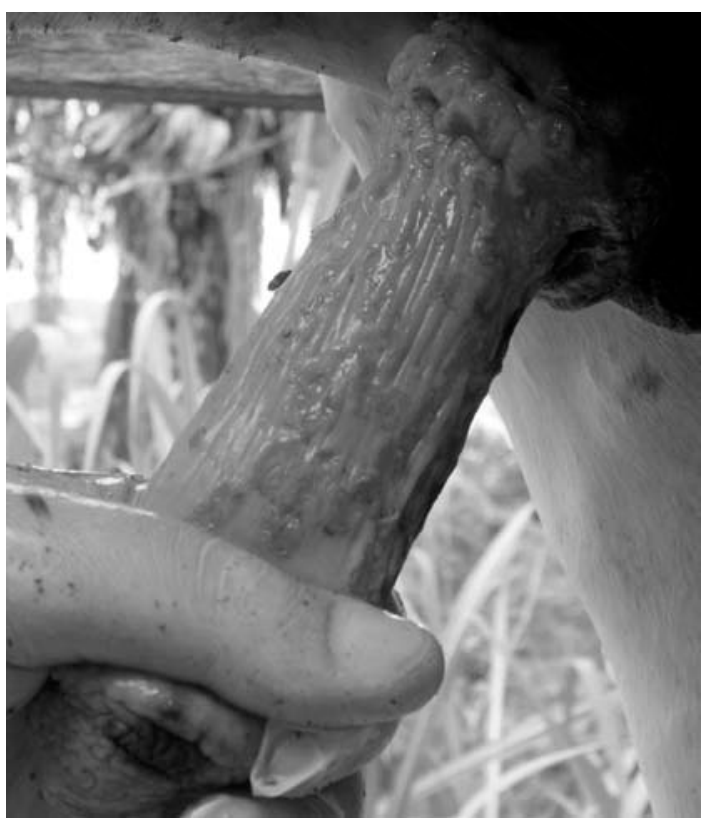

Figure 1. Equine coital exanthema in the glans penis of a stallion. Multiple multifocal to coalescing ulcers 0.2 to $1 \mathrm{~cm}$ diameter, elevated edges and a hyperemic ulcerated center covered with fibrinous exudate.

Histologically, there were focally extensive areas of ulceration in the mucosa of the penis with a mixed inflammatory infiltrate, composed by neutrophils, lymphocytes, macrophages, and rare eosinophils, associated with moderate multifocal necrosis with accumulation of fibrin (Figure 2), which was extended to the adjacent connective tissue. There was acanthosis at the boundary between ulcerated and intact mucosa with moderate multifocal degenerative vacuolization of epithelial cells in the basal and spinosum layers. A mild neutrophilic infiltrate was observed within the epithelium and in the superficial connective tissue in the mucosa. In the deeper connective tissue of the mucosa, the inflammatory infiltrate was predominantly composed of lymphocytes and macrophages. Therefore, a morphological diagnosis of multifocal severe ulcerative and fibrinous necrotizing balanoposthitis was established, which is consistent with equine coital exanthema.

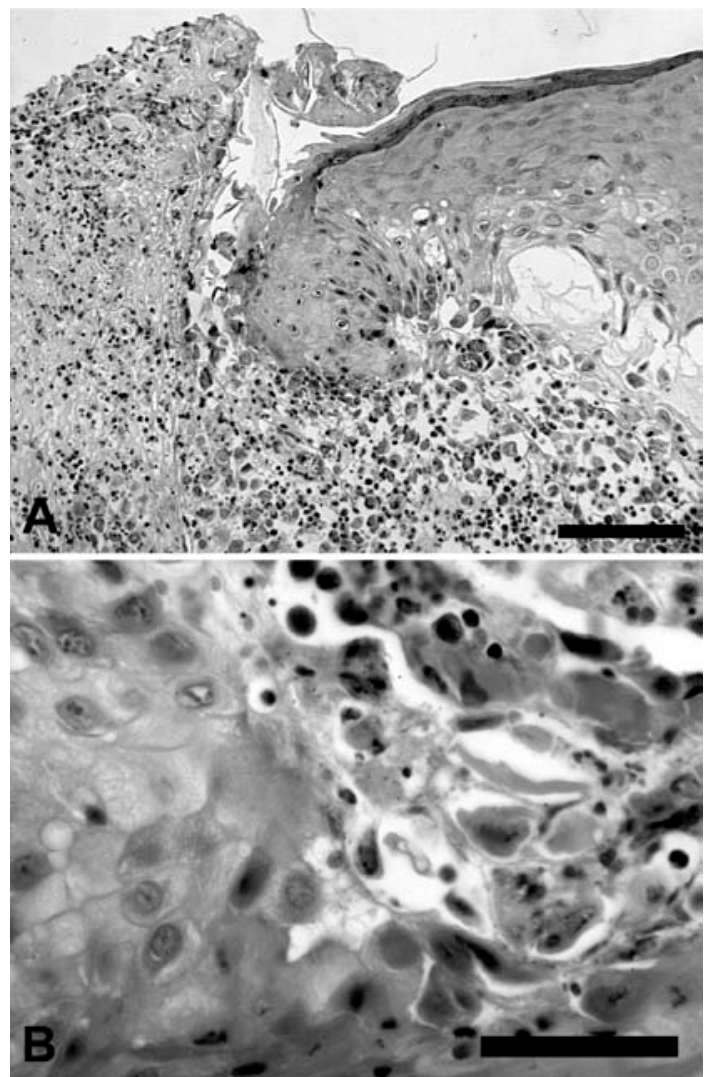

Figure 2. Equine coital exanthema in the glans penis of a stallion. Ulcerative fibrinous-necrotizing multifocal balanoposthitis, characterized by (A) deep ulceration of the mucosa with a marked mixed inflammatory infiltrate, associated with mild multifocal necrosis and fibrin accumulation. Acanthosis and vacuolar degeneration of the epithelium adjacent to the ulcerated area. HE, bar = $100 \mu \mathrm{m}$. (B) Epithelial degeneration and acantholysis. HE, bar $=50 \mu \mathrm{m}$.

Fragments of the lesions and blood samples collected in EDTA were obtained for DNA extraction and PCR. DNA extraction from whole blood and tissues was performed using a previously 
described silica method (Boom et al., 1990). PCR for detection of EHV-3 genomic DNA was performed with primer sets targeting the viral gene encoding the glycoprotein $\mathrm{G}$ (gG), as described by Dynon et al. (2001). Locations and sequences of primers were as follows: (sense: 792-812) 5'GCGCTCTCTCGGCCTTGCCAG-3' and (antisense: 1309-1290) 5'-GGCGTCTCGAAAAGCGAGAG-3'. Amplification reactions were performed in $25 \mu \mathrm{L}$ containing $10 \mathrm{mM}$ Tris-HCl (pH 8.0), $2 \mathrm{mM} \mathrm{MgCl}_{2}$, 200mM each dNTP (Invitrogen-BRL), 20pM each primer, 2U Taq DNA polymerase (InvitrogenBRL), and 200ng template DNA. Cycling conditions included five minutes at $95^{\circ} \mathrm{C}, 30$ cycles of $94^{\circ} \mathrm{C}$ for one minute, $60^{\circ} \mathrm{C}$ for one minute, and $72^{\circ} \mathrm{C}$ for one minute, followed by a final extension for 7 minutes at $72^{\circ} \mathrm{C}$. PCR products were analyzed by $1.5 \%$ agarose gel electrophoresis with ethidium bromide staining. Mammalian GADPH was amplified as an internal control of the amplification efficiency, as previously described (Shi and RoyBurman, 2000).

A single amplification product of approximately 518-bp was observed in the DNA extracted from the skin lesions on the scrotum and prepuce. A similar product was observed from the EDTAcollected blood sample. The PCR product from tissues was sequenced three times in the forward and reverse directions (ET Dynamic Terminator MEGABACE, GE HealthCare - UK) by automated DNA sequencing (MegaBaceTM 1000 Amersham Biosciences - UK). Nucleotide sequences were assembled using the CAP3 Sequence Assembling Program (http://asparagin.cenargen.embrapa.br/phph/). A GenBank search revealed an identity rate of $99 \%$ and $100 \%$ at the nucleotide and deduced amino acid sequence levels, respectively, with the EHV-3 reference strain 334/74 (accession number AF081188). The partial nucleotide sequence of the glycoprotein $\mathrm{G}$ (gG) gene obtained in this study was deposited in GenBank (Accession number GQ336877).

The stallion was treated with sulfa trimethoprim (Trissulfin ${ }^{\circledR}$ injectable solution - Ouro Fino Saúde Animal Ltda - São Paulo, SP, Brazil) (15mg/kg), intravenous (IV), for seven days. The stallion was also given Ketoprofen (Ketojet ${ }^{\circledR}$ oral - Agener União - Fortaleza, CE, Brazil) (2.2mg/kg), orally once a day for five days. Local treatment included iodine solution (Iodopovidona 10\% Filaderme Geyer Medicamentos S.A. - Porto Alegre, RS, Brazil), diluted ointment of essential fatty acids (Ricinus assept, Vansil Indústria Veterinária, Descalvado, SP, Brazil) and insecticide spray (Bactrovet ${ }^{\circledR}$ Prata - König - Avellaneda, Argentina) for preventing screwworm infection. After 15 days of treatment, the lesions were completely healed. Depigmentation of the skin remained where the lesions were previously located, particularly in the prepuce and scrotum.

Keywords: stallion, equine herpesvirus 3, erosiveulcerative skin lesion, prepucial region

\section{RESUMO}

Em agosto de 2008, um garanhão da raça Mangalarga Marchador, de quatro anos de idade, com histórico clínico de apatia, inapetência e edema de prepúcio e escroto, apresentou, ao exame clínico, exsudato purulento fluindo pelo óstio prepucial, prepúcio e mucosa peniana com inúmeras lesões circulares de bordos elevados e hiperêmicos, centro ulcerado recoberto por material amarelado de aspecto fibrinoso, com distribuição multifocal. Histologicamente, a mucosa peniana apresentou áreas de ulceração associadas a infiltrado inflamatório misto, com necrose multifocal e moderado acúmulo de fibrina, que se estendiam para o tecido conjuntivo adjacente. O diagnóstico morfológico foi de balanopostite ulcerativa fibrino-necrótica multifocal intensa, similar ao encontrado em casos de exantema coital equino (ECE), causado pelo herpesvírus equino 3 (EHV-3). Amostra de pele do prepúcio e sangue, colhido em EDTA, foram submetidos a ensaios de PCR específicos para EHV-3, observando-se a amplificação de um produto de tamanho esperado de 518pb. A detecção do EHV-3 foi confirmada por meio de seu sequenciamento, sendo a sequência de nucleotídeos depositada no GenBank sob o número GQ336877. As sequências de nucleotídeos e as de aminoácidos deduzidos apresentaram identidade de 99\% e 100\%, respectivamente, com a sequência de EHV-3 disponível no GenBank, número AF081188. Após 15 dias de tratamento, houve completa cicatrização das lesões, com despigmentação da pele, principalmente, no prepúcio e na bolsa escrotal. Com base nos achados clínicos, histopatológicos, PCR e sequenciamento, concluiu-se tratar de um caso de exantema coital equino, sendo o primeiro com confirmação definitiva do agente etiológico no Brasil.

Palavras-chave: garanhão, herpesvírus equino 3, lesões erosivoulcerativas, região prepucial 


\section{ACKNOWLEDGEMENTS}

The authors thank for felloships granted by the Conselho Nacional de Desenvolvimento Científico e Tecnológico (CNPq) and John Simon Guggenheim Memorial Foundation and to the $\mathrm{CNPq}$ and Fundação de Amparo à Pesquisa do Estado de Minas Gerais for the lab financial support.

\section{REFERENCES}

BARRANDEGUY, M.; VISSANI, A.; OLGUIN, L. et al. Experimental reactivation of equine herpesvirus-3 following corticosteroid treatment. Equine Vet. J., v.40, p.593-595, 2008.

BRYANS, J.T. Herpesviral diseases affecting reproduction in the horse. Vet. Clin. N. Am.: Large Anim. Pract., v.2, p.203-212, 1980.

CRANDELL, R.A.; DAVIS, E.R. Isolation of equine coital exanthema virus (equine herpesvirus 3) from the nostril of a foal. $J$. Am. Vet. Med. Assoc., v.187, p.503-504, 1985.

DYNON, K.; VARRASCO, A.; FICORILLI, N. et al. Identification of equine herpesvirus 3 (equine coital exanthema virus), equine gammaherpesviruses 2 and 5, equine adenoviruses 1 and 2, equine arteritis virus and equine rhinitis $\mathrm{A}$ virus by polymerase chain reaction. Aust.Vet. J., v.79, p.695-702, 2001.

GIRARD, A.; GREIG, A.S.; MITCHELL, D. et al. Virus associated with vulvitis and balanitis in the horse - a preliminary report. Can. J. Comp. Med., v.32, p.603-604, 1968.
KROGSRUD, J.; ONSTAD, O. Equine coital exanthema. Isolation of a virus and transmission experiments. Acta Vet. Scand., v.12, p.1-14, 1971.

METCALF, E.S. The role of international transport of equine semen on disease transmition. Anim. Reprod. Sci., v.68, p.229-237, 2001.

MURPHY, F.A.; GIBBS, E.P.J.; HORZINEK, M.C. et al. Herpesviridae. In: MURPHY, F.A.; GIBBS, E.P.J.; HORZINEK, M.C. et al. Veterinary virology. 3.ed. San Diego: Academic, 1999. p.301-326.

PASCOE, R.R. The effect of equine coital exanthema on the fertility of mares covered by stallions exhibiting the clinical disease. Aust. Vet. J., v.57, p.111-114, 1981.

PASCOE, R.R.; BAGUST, T.J. Coital exanthema in stallions. J. Reprod. Fertil., v.23, Suppl., p.147-150, 1975.

SEKI, Y.; SEIMIYA, Y.M.; YAEGASHI, G. et al. Occurrence of Equine Coital Exanthema in pastured draft horses and isolation of equine herpesvirus 3 from progenital lesions. J. Vet. Med. Sci., v.66, p.1503-1508, 2004.

SHI, Y.; ROY-BURMAN, P. A novel truncated env gene isolated from a Feline Leukemia Virusinduced thymic lymphosarcoma. J. Virol., v.74, p.1451-1456, 2000. 